\begin{tabular}{l} 
Bentham OPEN \\
CrossMark \\
\hline
\end{tabular}

\title{
LETTER
}

\section{Letter to the Editor: Bilateral Subconjunctival Hemorrhage in a 3-Year-Old Girl with Mycoplasma Pneumonia}

\author{
Tatsuya Mimura $^{1,2, *}$, Hidetaka Noma ${ }^{3}$ and Satoru Yamagami ${ }^{1,2}$ \\ ${ }^{\prime}$ Department of Ophthalmology, Tokyo Women's Medical University Medical Center East, Tokyo, Japan \\ ${ }^{2}$ Department of Ophthalmology, University of Tokyo Graduate School of Medicine, Tokyo, Japan \\ ${ }^{3}$ Department of Ophthalmology, Hachioji Medical Center, Tokyo Medical University, Tokyo, Japan
}

\begin{abstract}
We report an unusual case of bilateral subconjunctival hemorrhage following mycoplasma pneumonia. A healthy 3-yearold girl developed bilateral subconjunctival hemorrhage at 4 days after the onset of fever and respiratory symptoms such as running nose, cough, and wheezing. Laboratory data were normal except for elevation of Mycoplasma pneumoniae antibodies. The patient was followed without treatment and the subconjunctival hemorrhage resolved in both eyes within two weeks. To the best of our knowledge, this is the first report of subconjunctival hemorrhage following mycoplasma pneumonia. Respiratory symptoms such as cough and wheezing may cause bilateral subconjunctival hemorrhage in infants.
\end{abstract}

Keywords: Subconjunctival, Hemorrhage, Mycoplasma, Pneumonia, Bilateral, Antibodies.

\section{INTRODUCTION}

Mycoplasma pneumonia is a common respiratory tract infection. Mycoplasma pneumoniae infection is associated with extrapulmonary manifestations in up to $25 \%$ of children that are sometimes more severe and of greater clinical importance than the primary respiratory tract infection [1]. Several cases of mycoplasma pneumonia-associated mucositis and conjunctivitis have been reported in children [2 - 10], but subconjunctival hemorrhage caused by Mycoplasma Pneumoniae has never been reported before. Here, we report an extremely rare case of bilateral subconjunctival hemorrhage in a 3-year-old girl after upper respiratory tract infection with Mycoplasma Pneumoniae.

\section{CASE REPORT}

A 3-year-old girl was referred to our hospital with a 1-day history of painless bilateral subconjunctival hemorrhage and a 5-day history of running nose, cough, and wheezing. Mycoplasma pneumoniae antibody titer (immunoglobulins IgG and IgM) was 1:640. Mycoplasma pneumonia had been diagnosed based on serum antibody titers and she had been treated with oral azithromycin $(10 \mathrm{mg} / \mathrm{kg}$ once daily) for three days at presentation. She developed pneumothorax associated with persistent cough and wheezing, so her bilateral subconjunctival hemorrhage may have been caused by coughing. The cornea, anterior chamber, iris, and lens were normal in both eyes. Funduscopy was within normal limits. There was no coagulopathy and no history of trauma or other medical problems. The patient did not have ocular pain, photophobia, itching, discharge, or headache. She was followed without treatment because her subconjunctival hemorrhages were asymptomatic Fig. (1). Subconjunctival hemorrhage was still detected in both eyes at one week after the onset, but complete resolution was achieved within two weeks.

\footnotetext{
* Address correspondence to this author at the Department of Ophthalmology, Tokyo Women's Medical University Medical Center East, 2-1-10 Nishiogu, Arakawa-ku, Tokyo 116-8567, Japan, Tel: +81-3-3810-1111 (Ex7765), Fax: +81-3-3894-0282; E-mail: mimurat-tky@umin.ac.jp
} 

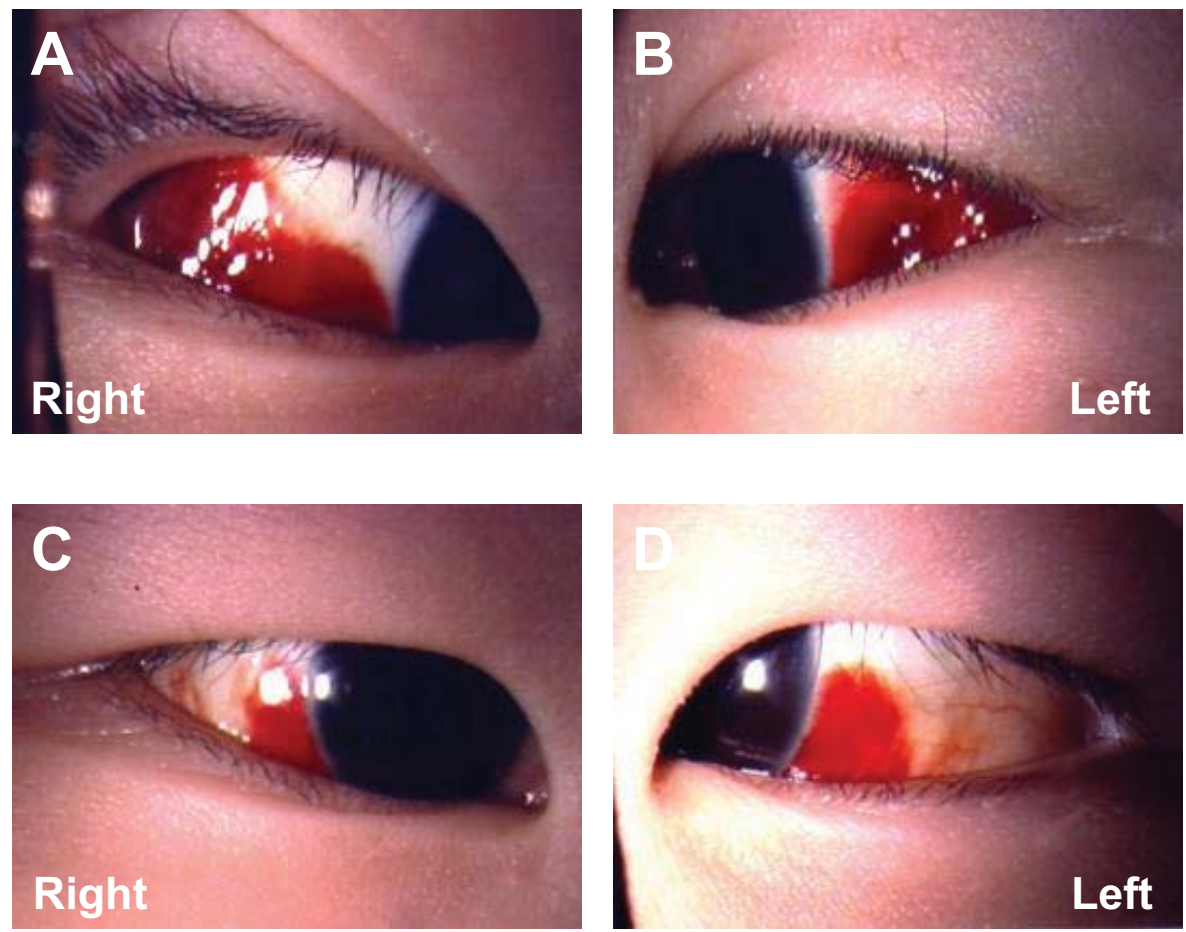

Fig. (1). Slit-lamp photomicrographs of the anterior segment of both eyes at 1 day $(A, B)$ and one week $(C, D)$ after the onset of bilateral subconjunctival hemorrhage.

\section{DISCUSSION}

Subconjunctival hemorrhage is extremely rare after Mycoplasma pneumoniae infection and has never been reported previously. Infectious conjunctivitis is the most frequent ocular manifestation of Mycoplasma pneumoniae infection [2 10], while other rare ocular manifestations include amaurosis (Cvenkel 2003) [11], optic papillitis [12], and anterior uveitis [13 - 16]. These manifestations may be closely related to inflammation, infection, and tissue damage caused by this mycoplasma. However, our patient did not have inflammatory or infectious conjunctivitis and her subconjunctival hemorrhage could not be explained by direct infection of the conjunctiva. Subconjunctival hemorrhage can be associated with common systemic vascular disorders such as hypertension and arteriosclerosis $[17,18]$, as well as with diabetes [17, 18], trauma [17, 18], acute hemorrhagic conjunctivitis, anticoagulant therapy, conjunctivochalasis [19], and wearing contact lenses [20]. Subconjunctival hemorrhage sometimes also results from prolonged coughing, vomiting, or a Valsalva maneuver [21]. Such sudden stress can induce hemorrhage in the orbit, anterior chamber, retina, or subconjunctival space [22]. Our patient developed pneumothorax associated with persistent cough and wheezing, so her bilateral subconjunctival hemorrhage may have been caused by coughing and/or the Valsalva maneuver with elevation of the blood pressure. Increased venous pressure and congestion during the Valsalva maneuver might have led to bilateral subconjunctival hemorrhage in our patient [22].

In conclusion, this is the first report of bilateral subconjunctival hemorrhage in a patient with mycoplasma pneumonia. Ophthalmologists should be aware that respiratory symptoms such as coughing and vomiting or the Valsalva maneuver can cause bilateral subconjunctival hemorrhage in infants with respiratory tract infections.

\section{ETHICS APPROVAL AND CONSENT TO PARTICIPATE}

The study was approved by the Human Ethics Committee Review Board following the Declaration of Helsinki in 1995 at the Faculty of Tokyo Women's Medical University Medical Center East.

\section{HUMAN AND ANIMAL RIGHTS}

No Animals were used in this research. All human research procedures followed were in accordance with the ethical standards of the committee responsible for human experimentation (Tokyo Women's Medical University Medical Center East, Tokyo, Japan), and with the Helsinki Declaration of 1975, as revised in 2008. 


\section{CONSENT FOR PUBLICATION}

Not applicable.

\section{GRANTS AND FUNDS}

This work was supported in part by a Grant-in-Aid for Scientific Research from the Ministry of Education, Culture, Sports, Science (16K11332).

\section{PROPRIETARY INTEREST}

The authors do not have any proprietary interest in this manuscript.

\section{CONFLICT OF INTEREST}

The authors declare no conflict of interest, financial or otherwise.

\section{ACKNOWLEDGMENTS}

Declared none.

\section{REFERENCES}

[1] Waites KB, Talkington DF. Mycoplasma pneumoniae and its role as a human pathogen. Clin Microbiol Rev 2004; 17(4): 697-728. [http://dx.doi.org/10.1128/CMR.17.4.697-728.2004] [PMID: 15489344]

[2] Salzman MB, Sood SK, Slavin ML, Rubin LG. Ocular manifestations of Mycoplasma pneumoniae infection. Clin Infect Dis 1992; 14(5): 1137-9. [http://dx.doi.org/10.1093/clinids/14.5.1137] [PMID: 1600016]

[3] Vanfleteren I, Van Gysel D, De Brandt C. Stevens-Johnson syndrome: A diagnostic challenge in the absence of skin lesions. Pediatr Dermatol 2003; 20(1): 52-6.

[http://dx.doi.org/10.1046/j.1525-1470.2003.03012.x] [PMID: 12558848]

[4] Schalock PC, Dinulos JG, Pace N, Schwarzenberger K, Wenger JK. Erythema multiforme due to Mycoplasma pneumoniae infection in two children. Pediatr Dermatol 2006; 23(6): 546-55. [http://dx.doi.org/10.1111/j.1525-1470.2006.00307.x] [PMID: 17155996]

[5] Ravin KA, Rappaport LD, Zuckerbraun NS, Wadowsky RM, Wald ER, Michaels MM. Mycoplasma pneumoniae and atypical StevensJohnson syndrome: A case series. Pediatrics 2007; 119(4): e1002-5. [http://dx.doi.org/10.1542/peds.2006-2401] [PMID: 17353300]

[6] Zipitis CS, Thalange N. Intravenous immunoglobulins for the management of Stevens-Johnson syndrome with minimal skin manifestations. Eur J Pediatr 2007; 166(6): 585-8.

[http://dx.doi.org/10.1007/s00431-006-0287-9] [PMID: 17008995]

[7] Latsch K, Girschick HJ, Abele-Horn M. Stevens-Johnson syndrome without skin lesions. J Med Microbiol 2007; 56(Pt 12): 1696-9. [http://dx.doi.org/10.1099/jmm.0.47318-0] [PMID: 18033843]

[8] McGouran DC, Petterson T, McLaren JM, Wolbinski MP. Mucositis, conjunctivitis but no rash - The "Atypical Stevens - Johnson syndrome". Acute Med 2011; 10(2): 81-2. [PMID: 22041607]

[9] Bressan S, Mion T, Andreola B, Bisogno G, Da Dalt L. Severe Mycoplasma pneumoniae-associated mucositis treated with immunoglobulins. Acta Paediatr 2011; 100(11): e238-40 [http://dx.doi.org/10.1111/j.1651-2227.2011.02342.x] [PMID: 21535132]

[10] Hochreiter D, Jackson JM, Shetty AK. Fever, severe mucositis, and conjunctivitis in a 15-year-old male. Clin Pediatr (Phila) 2012; 51(11): 1103-5

[http://dx.doi.org/10.1177/0009922812460915] [PMID: 23034945]

[11] Cvenkel B. Bilateral transient amaurosis following Mycoplasma pneumoniae infection: A manifestation of acute disseminated encephalomyelitis. Eye (Lond) 2003; 17(5): 673-5. [http://dx.doi.org/10.1038/sj.eye.6700424] [PMID: 12855991]

[12] Liu EM, Janigian RH. Mycoplasma pneumoniae: The other masquerader. JAMA Ophthalmol 2013; $131(2): 251-3$. [http://dx.doi.org/10.1001/jamaophthalmol.2013.586] [PMID: 23411898]

[13] Dawidek GM. Anterior uveitis associated with Mycoplasma pneumoniae pneumonia. Postgrad Med J 1991; 67(786): $380-2$. [http://dx.doi.org/10.1136/pgmj.67.786.380] [PMID: 2068034]

[14] Di Maria A, Ruberto G, Redaelli C, Gualtieri G. Anterior uveitis associated with Mycoplasma pneumoniae pneumonia: A case report. Acta Ophthalmol Scand 1999; 77(3): 349-50. [http://dx.doi.org/10.1034/j.1600-0420.1999.770322.x] [PMID: 10406161] 
[15] Yashar SS, Yashar B, Epstein E, Viani RM. Uveitis associated with Mycoplasma pneumoniae meningitis. Acta Ophthalmol Scand 2001; 79(1): 100-1.

[http://dx.doi.org/10.1034/j.1600-0420.2001.079001100.x] [PMID: 11167302]

[16] Weinstein O, Shneck M, Levy J, Lifshitz T. Bilateral acute anterior uveitis as a presenting symptom of Mycoplasma pneumoniae infection. Can J Ophthalmol 2006; 41(5): 594-5. [http://dx.doi.org/10.1016/S0008-4182(06)80028-1] [PMID: 17016530]

[17] Mimura T, Usui T, Yamagami S, et al. Recent causes of subconjunctival hemorrhage. Ophthalmologica 2010; $224(3)$ : 133-7. [http://dx.doi.org/10.1159/000236038] [PMID: 19738393]

[18] Mimura T, Yamagami S, Usui T, et al. Location and extent of subconjunctival hemorrhage. Ophthalmologica 2010; $224(2)$ : 90-5. [http://dx.doi.org/10.1159/000235798] [PMID: 19713719]

[19] Mimura T, Usui T, Yamagami S, et al. Subconjunctival hemorrhage and conjunctivochalasis. Ophthalmology 2009; 116(10): 1880-6. [http://dx.doi.org/10.1016/j.ophtha.2009.03.021] [PMID: 19596440]

[20] Mimura T, Yamagami S, Mori M, et al. Contact lens-induced subconjunctival hemorrhage. Am J Ophthalmol 2010; 150(5): 656-665.e1. [http://dx.doi.org/10.1016/j.ajo.2010.05.028] [PMID: 20709310]

[21] Leibowitz HM. The red eye. N Engl J Med 2000; 343(5): 345-51. [http://dx.doi.org/10.1056/NEJM200008033430507] [PMID: 10922425]

[22] Paysse EA, Coats DK. Bilateral eyelid ecchymosis and subconjunctival hemorrhage associated with coughing paroxysms in pertussis infection. J AAPOS 1998; 2(2): 116-9.

[http://dx.doi.org/10.1016/S1091-8531(98)90075-1] [PMID: 10530974]

\section{(C) 2017 Mimura et al.}

This is an open access article distributed under the terms of the Creative Commons Attribution 4.0 International Public License (CC-BY 4.0), a copy of which is available at: https://creativecommons.org/licenses/by/4.0/legalcode. This license permits unrestricted use, distribution, and reproduction in any medium, provided the original author and source are credited. 